\title{
NOTE
}

\section{Characteristics of DMSP-lyase in Phaeocystis sp. (Prymnesiophyceae)}

\author{
Jacqueline Stefels $^{1, \bullet}$, Lubbert Dijkhuizen ${ }^{2}$ \\ ${ }^{1}$ Department of Marine Biology, University of Groningen, PO Box 14, 9750 AA Haren, Netherlands \\ ${ }^{2}$ Department of Microbiology, University of Groningen, PO Box 14,9750 AA Haren, Netherlands
}

\begin{abstract}
The marine phytoplankton species Phaeocystis $\mathrm{sp}$. is one of the few microalgae known to be able to convert dimethylsulfoniopropionate (DMSP) enzymatically into dimethyl sulfide (DMS) and acrylic acid. The function of this enzymatic process for the organism is not known. From experiments with crude extracts and whole cells of axenic cultures of Phaeocystis it was concluded that DMSP-lyase is membrane-bound and located extracellularly because: (1) the enzyme activity in extracts and in whole cells varied in a similar manner with $\mathrm{pH}_{\mathrm{i}}(2)$ between 50 and $80 \%$ of the DMSPlyase activity was associated with the membrane fraction; (3) lyase activity in whole cells was inhibited by the nonpermeable thiol-reagent $p$-chloromercuribenzenesulfonic acld ( $p$ CMBS). The pH optimum was 10.5 or higher, which is in contrast with available data for the enzyme from other organisms. The $\mathrm{pH}$ profile, the requirement for reduced thiol groups in extracts and the inhibition by $p$ CMBS suggest the involvement of cysteine residues at the active site. Production of DMSP as well as its cleavage by DMSP-lyase are apparently not involved in the short term regulation of the osmotic potential of cells upon changes in salinity.
\end{abstract}

KEY WORDS: DMSP-lyase - DMSP - DMS - Phaeocystis Phytoplankton

The production of the most important volatile organo sulfur compound in the marine environment, dimethyl sulfide (DMS), occurs mainly through enzymatic cleavage of its precursor, dimethylsulfoniopropionate (DMSP). DMSP is produced by several groups of macro- and microalgae (Keller et al. 1989, Blunden et al. 1992). Since research began on the production of DMS in the marine environment, many suggestions have been made on the physiological role of DMSP. Most research has focused on the possible contribution of DMSP to the regulation of the cellular osmotic potential. Indeed, the compatibility of this solute with

·E-mail: stefelsj@biol.rug.n! algal metabolism was confirmed in studies on the impact of DMSP on enzyme activities in extracts of the marine phytoplankter Tetraselmis subcordiformis (Gröne \& Kirst 1991). Several authors have reported an increased cellular DMSP concentration at higher salinity levels (Vairavamurthy et al. 1985, Dickson \& Kirst 1986, 1987a, b), but rapid changes in the intracellular concentrations of DMSP upon salinity changes were not always observed (van Diggelen et al. 1986, Edwards et al. 1987, Stefels et al. in press). Others suggested a function as cryoprotectant (Kirst et al. 1991, Nishiguchi \& Somero 1992), methyl donor (Ishida 1968) or sulfur storage (van Diggelen et al. 1986). It has also been hypothesized that DMSP can substitute for other compatible solutes, e.g. those containing nitrogen under N-deficient conditions (Turner et al. 1988, Gröne \& Kirst 1992).

With the function of DMSP within the algal cell still unclear, mechanisms involved in the regulation of intracellular DMSP levels are also under discussion. Only a few reports on the partial purification of the DMSP-lyase enzyme responsible for the cleavage of DMSP have appeared. The enzyme has been found in the macroalga Polysiphonia lanosa (Cantoni \& Anderson 1956) and the heterotrophic dinoflagellate Gyrodinium cohnii (Ishida 1968). More reports have focused on the ability of microorganisms to produce DMS from DMSP (Kadota \& Ishida 1972). Several aerobic as well as anaerobic bacterial strains able to cleave DMSP have been isolated from tidal flat areas (Quist \& van der Maarel pers. comm.). A bacterium has been isolated from the Sargasso Sea which cleaves DMSP into DMS and acrylate (Ledyard \& Dacey 1994). It in fact grows on acrylate, which the bacterium uses for its carbon source, and does not further metabolize DMS. The first homogeneous DMSP-lyase protein preparation 
has recently been obtained from a marine Alcaligeneslike bacterium (de Souza \& Yoch 1995). The many field data suggest that bacteria may play an important role in the conversion of DMSP to DM IS. Evidence for a contribution to the conversion of DMSP by algae has remained scarce, notwithstanding the fact that DMSP can account for 50 to $70 \%$ of total organic sulfur in some algal species (Matrai \& Keller 1994), and that the suggested functions of DMSP imply the presence of a mechanism to remove it from the cell. Recently, Stefels \& van Boekel (1993) reported the presence of DMSP lyase activity in axenic cultures of the Prymnesiophyte Phaeocystis sp. Moreover, in natural seawater samples taken during a spring bloom off the Dutch coast, DMSP-lyase activity was found to be highly correlated with Phaeocystis numbers (Stefels et al. 1995).

In the present study, we report on some of the characteristic properties of DMSP-lyase in crude extracts and whole cells of Phaeocystis sp. and discuss the possible role of this enzyme in cellular physiology.

Materials and methods. Algal strain and culturing conditions: An axenic strain of Phaeocystis sp. (strain K) was used and regularly checked for bacterial conta. mination using Hoechst dye no. 33258 and fluorescence microscopy (Paul 1982). The organism was grown in filtered, sterilized (by autoclaving) North Sea water to which minor salts, vitamins and nutrients were added as described by Veldhuis \& Admiraal (1987), with the exception that nitrate was the only nitrogen source. Cultures were grown in serum bottles placed on a rolling device, and incubated at $11^{\circ} \mathrm{C}$ and a light intensity of $85 \mu \mathrm{E} \mathrm{m} \mathrm{m}^{-2} \mathrm{~s}^{-1}$ in a $14 \mathrm{~h}$ light: $10 \mathrm{~h}$ dark cycle. Experiments with whole cells as well as with crude extracts were always performed with samples taken from the end-exponential growth phase to ensure physiologically comparable conditions.

Extract preparation: To $15 \mathrm{ml}$ culture aliquots, $5 \mathrm{ml}$ of a $50 \mathrm{mM}$ Tris buffer (prepared in seawater, $\mathrm{pH}$ 8.3) with dithiothreitol (DTT, minimal end concentration $1 \mathrm{mM}$ ) was added. Cells were harvested by centrifugation at $800 \times g$ for 20 min. Pellets were resuspended in the same Tris/DTT buffer, and disrupted using a French Pressure cell at $130 \mathrm{MPa}$. Buffer conditions during the experiments are given below.

Assay for DMSP-Iyase activity: DMSP. $\mathrm{HCl}$ was used as substrate in the enzyme assay. Primary DMSP standards of approximately $10 \mathrm{mM}$ were prepared in seawater and stored frozen. All assays were performed in 14 or $60 \mathrm{ml}$ vials stoppered with a teflon Mininert valve. Vials were placed in the dark in a constanttemperature waterbath, usually at a temperature of $20^{\circ} \mathrm{C}$ unless stated otherwise. The standard assay mixture for crude extracts $(5 \mathrm{ml})$ contained $50 \mathrm{mM}$ Tris buffer ( $\mathrm{pH}$ 8.3) with 3 to $3.7 \mathrm{mM}$ DTT and an extract concentration of approximately $0.5 \mu \mathrm{g}$ protein $\mathrm{ml}^{-1}$. In whole cell assays, the mixture $(5 \mathrm{ml})$ contained culture aliquots ( 2 to $4 \times 10^{5}$ cells $\mathrm{ml}^{-1}$, equivalent to approximately 2 to $4 \mu \mathrm{g}$ protein $\mathrm{ml}^{-1}$ ) and $20 \mathrm{mM}$ Bis-Tris Propane (BTP) buffer (pH 8.6). Deviations from the standard procedure in specific experiments are indicated. Reactions were started by addition of $100 \mu \mathrm{M}$ DMSP. Under regular shaking of the vials, DMS evolution was measured in the headspace over $60 \mathrm{~min}$, at 15 min intervals. A $100 \mu$ gas sample from the headspace of the vial was injected into a Varian 3600 gas chromatograph equipped with a sulfur-specific Hall Electrolytic Conductivity Detector (Stefels \& van Boekel 1993). For practical reasons, the substrate concentrations used in the experiments did not saturate the enzyme. During the $1 \mathrm{~h}$ assay, the amount of substrate used was typically 2 to $6 \%$ of the initial concentration. and never exceeded $12 \%$, resulting in activities linear in time (with typical $\mathrm{r}^{2}$ values of 0.996 ) and proportional to enzyme concentrations. After each experiment, the pH of the assay mixture was checked. A calibration curve was prepared from DMSP standards in seawater to which $\mathrm{NaOH}$ was added (final concentration $1 \mathrm{M}$ ), resulting in an equimolar conversion of DMSP into DMS and acrylic acid (White 1982, Dacey \& Blough 1987). Working standards were stored under the same conditions as assay samples. To obtain absolute values, DMS concentrations calculated from the working standards were multiplied by 1.4 , to correct for the difference in gas/liquid equilibrium of DMS in samples with (the standards) or without (the assay samples) $1 \mathrm{M} \mathrm{NaOH}$.

Protein measurements: Whole cell samples (harvested by centrifugation at $800 \times g$ for $20 \mathrm{~min}$ ) and 200 to $400 \mu$ aljquots of crude extracts were treated with boiling $\mathrm{NaOH}(0.5 \mathrm{M})$ for 15 min and centrifuged subsequently. Supernatants were analysed with the BioRad protein assay. Bovine serum albumin (BSA) was used as a standard.

Experiments with crude cell extracts: Extracts prepared from large cell numbers were first tested in dilution experiments to ascertain that DMSP-lyase activity was proportional to the amount of extract used.

Effect of DTT on enzyme activity: Crude extracts were prepared in $25 \mathrm{mM}$ Tris buffer with $1 \mathrm{mM}$ DTT $(\mathrm{pH} 8.0) ; 100$ ul samples were then added to $20 \mathrm{ml}$ $25 \mathrm{mM}$ Tris buffer with increasing DTT concentrations (5 $\mu \mathrm{M}$ to $5 \mathrm{mM}$ DTT). Following addition of $145 \mu \mathrm{M}$ DMSP, DMS production over time was measured

Effect of $p H$ on enzyme activity: Crude extracts were prepared in $50 \mathrm{mM}$ Tris buffer ( $\mathrm{pH} \mathrm{8.5,} \mathrm{in} \mathrm{30 \%} \mathrm{NaCl)}$ with $5 \mathrm{mM}$ DTT. A pH range from 4.5 to 10.5 was prepared with a buffer complex. For the $\mathrm{pH}$ range 4.5 to 8 , a combination was made of $200 \mathrm{mM}$ acetic acid + $200 \mathrm{mM} \mathrm{NaH}_{2} \mathrm{PO}_{4} \cdot \mathrm{H}_{2} \mathrm{O}+200 \mathrm{mM}$ Tris in $30 \% \mathrm{NaCl}$ 
for the $\mathrm{pH}$ range 8.5 to $10.5,200 \mathrm{mM} \mathrm{NaHCO}_{3}$ was added to the former complex. The pH. was set by adding $\mathrm{HCl}$ or $\mathrm{NaOH}$. In the assay, the final concentration of the buffer components was $50 \mathrm{mM}$ and of DTT $3.7 \mathrm{mM}$. Assays were started by addition of $110 \mu \mathrm{M}$ DMSP. Control samples for abiotic conversion of DMSP were treated in exactly the same way but without addition of the extract.

Effect of salinity and $\mathrm{NaCl}$ on enzyme activity: Crude extracts were prepared in $50 \mathrm{mM}$ Tris buffer $(\mathrm{pH} 8.5$, prepared in $\mathrm{NaCl}$ ) with $5 \mathrm{mM}$ DTT. A salinity range from 0 to $50 \%$ S was prepared by dilution or evaporation of a natural seawater sample; $0 \% \mathrm{~S}$ was equivalent to $100 \%$ demineralized water. Also, an $\mathrm{NaCl}$ range with comparable ionic strength was prepared (500 $\mathrm{mM} \mathrm{NaCl}=31 \% \mathrm{~S}$ ). All samples were Tris/DTT buffered ( $\mathrm{pH}$ 8.7). Assays were started by addition of $110 \mu \mathrm{M}$ DMSP. Abiotic conversion of DMSP was checked for the highest and lowest salinity values only. Salinity was measured with a WTW Microprocessor Conductivity Meter LF 196.

Determination of kinetic properties: For practical purposes, the apparent $K_{\mathrm{m}}$ and $V_{\max }$ values were determined in crude extracts under non-optimal conditions (pH 8.3), using the initial rate of DMS production over a range of 0 to $15 \mathrm{mM}$ DMSP. The assays were performed in $100 \mathrm{mM}$ Tris/DTT buffer. After addition of DMSP from a neutralized stock solution, the rate of abiotic conversion in the buffer was measured first then the assay was started with the addition of $50 \mu \mathrm{l}$ crude extract

Experiments with whole cells: Proportionality between enzyme activity and cell concentration was confirmed in dilution experiments.

Effect of temperature on enzyme activity: Culture aliquots of $20 \mathrm{ml}$ were incubated at 5 different temperatures for $30 \mathrm{~min}$, along with their own DMSP standard range for calibration. Abiotic conversion of DMSP was measured using GF/F-filtered culture medium, treated in the same way as whole cell samples. Assays were started by addition of $50 \mu \mathrm{M}$ DMSP.

Effect of $\mathrm{pH}$ on enzyme activity: A pH range from 7.5 to 9.5 was prepared in 2 different buffers: $200 \mathrm{mM}$ Tris $(p K a=8.3)$ and $200 \mathrm{mM} \mathrm{BTP}\left(p K a_{1}=6.8, p K a_{2}=9.0\right)$, both in seawater. The assay mixture contained $4.5 \mathrm{ml}$ of culture and $0.5 \mathrm{ml}$ buffer. Assays were started by addition of $50 \mu \mathrm{M}$ DMSP. As a check for a possible deleterious effect of the buffers on living cells, a culture sample was analyzed in which the buffer was replaced with seawater Abiotic conversion of DMSP was measured in a Tris buffer series, in which the culture was replaced with seawater

Effect of salinity on enzyme activity: A salinity range from 6 to $56 \%$ S was prepared by dilution or evaporation of a natural seawater sample. Each sample was buffered with $20 \mathrm{mM}$ BTP buffer ( $\mathrm{pH}$ 9.4; comparable with the $\mathrm{pH}$ of late exponential phase cultures). Prior to the assay, aliquots of a culture $(34 \%$ S) were mixed $1: 1$ with one of the prepared salinity samples and incubated for $30 \mathrm{~min}$ at $16^{\circ} \mathrm{C}$. Final salinities ranged from 20 to $45 \%$ S. Assays were started by addition of $100 \mu \mathrm{M}$ DMSP. Abiotic conversion was measured by replacing the culture medium with autoclaved seawater which was then subjected to the same salinity range. The physiological condition of the cells was checked by following the DMS evolution in a parallel series of shocked cultures to which no DMSP was added. Increased DMS evolution from intracellular DMSP in axenic cultures of Phaeocystis can be regarded as an indicator for lysis (Stefels \& van Boekel 1993).

Localization of DMSP-lyase: Two experiments were performed: a membrane isolation from cell free extracts and an inhibition experiment with whole cells using the thiol-reagent p-chloromercuribenzenesulfonic acid ( $p$ CMBS) which acts only on the outside of cell membranes as a consequence of its large size.

Membrane fractions were isolated as follows: crude extract preparations were centrifuged at $2000 \times g$ for 10 min to sediment cell debris. Aliquots of the supernatants were used for estimation of total DMSP-lyase activity; the remainder was carefully suspended on a $50 \%$ sucrose layer and centrifuged for $1 \mathrm{~h}$ at $100000 \times \mathrm{g}$. The supernatant was used for estimation of the enzyme activity in the dissolved fraction; the membrane fraction was resuspended with the sucrose and subsequently assayed. The assay was performed in Tris/DTT buffer (pH 8.4). After addition of DMSP, the rate of abiotic conversion in the buffer was measured first, then assays were started by addition of $50 \mu \mathrm{ll}$ of the fractions.

Inhibition experiments with whole cells were performed: 1 series without a buffer and 2 series with BTP buffer $(20$ and $10 \mathrm{mM} \mathrm{BTP}$ at pH 8.6 and 9.4, respectively). Cultures were incubated with different concentrations of $p$ CMBS $(0.5,1$ and $2 \mathrm{mM})$ for 1 or $2 \mathrm{~h}$. Because preparations of $p$ CMBS from its sodium salt may be contaminated with small quantities of mercury chloride $\left(\mathrm{HgCl}_{2}\right)$ - also a thiol-reagent that acts in the same way as pCMBS, but it is able to penetrate the cell simultaneous incubation of culture aliquots with a range of $\mathrm{HgCl}_{2}$ concentrations was carried out, assuming a maximum dissociation of pCMBS of $10 \%$. Thus, $\mathrm{HgCl}_{2}$ concentrations of 50,100 and $200 \mu \mathrm{M}$ were used. As an abiotic control, GF/F-filtered culture medium was used and treated in the same way as culture samples. Assays were started by addition of $100 \mu \mathrm{M}$ DMSP.

Chemicals: DMSP.HCl was prepared according to Chambers et al. (1987) pCMBS and DTT were obtained from Fluka BioChemika; $\mathrm{HgCl}_{2}$ from Merck. 
Results. In contrast to whole cells, crude extract preparations required addition of DTT to maintain DMSP-lyase activity. A maximum activity was reached at DTT concentrations of $1 \mathrm{mM}$ (Fig. 1). At the minimum DTT concentration used in the assay $(5 \mu \mathrm{M})$, DMSP-lyase activity had dropped to $20 \%$ of the maximum. No inhibition by DTT was measured at higher concentrations (assays were performed up to $20 \mathrm{mM}$ DTT; data not shown). A DTT concentration of approximately $3 \mathrm{mMI}$ was used in subsequent experiments.

The DMSP-lyase activity in whole cells decreased with decreasing temperature (Fig. 2). Because the temperature optimum for growth of the Phaeocystis strain used lies between 12 and $21^{\circ} \mathrm{C}$ (van Boekel 1992), incubation temperatures for further experiments were chosen between 16 and $20^{\circ} \mathrm{C}$

Effect of $\boldsymbol{p H}$ on enzyme activity: In both extracts and whole cells, DMSP-lyase exhibited maximum activity at alkaline pH (Fig. 3). As abiotic decomposition of DMSP increases with increasing $\mathrm{pH}$, it became problematic to measure enzyme activity above $\mathrm{pH} 10.5$. At this $\mathrm{pH}$, abiotic conversion of DMSP contributed over $30 \%$ of total DMS production in the extract preparations. At $\mathrm{pH} 7$, enzyme activity had dropped to ca $25 \%$ of the activity at $\mathrm{pH} 10.5$. In experiments with whole cells, abiotic decomposition of DMSP contributed 4 to $8 \%$ of total DMS production at the maximum $\mathrm{pH}$ of 9.5. DMSP-lyase activities in whole cells and extracts displayed comparable $\mathrm{pH}$ profiles. Buffers in the whole cell experiments were chosen for their non-permeability through the cell membrane. Although it is known that Tris sometimes interferes with enzyme reactions, whereas BTP is thought to be inactive, samples without buffer more closely followed the Tris profile.

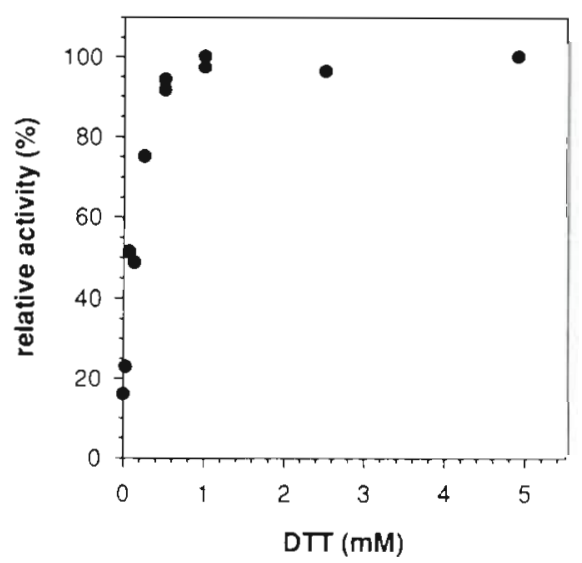

Fig. 1. Effect of dithiothreitol concentrations on DMSP-lyase activity in crude extracts of axenic Phaeocystis sp. cultures. expressed as percentage of the maximum activity; data are corrected for abiotic DMSP conversion

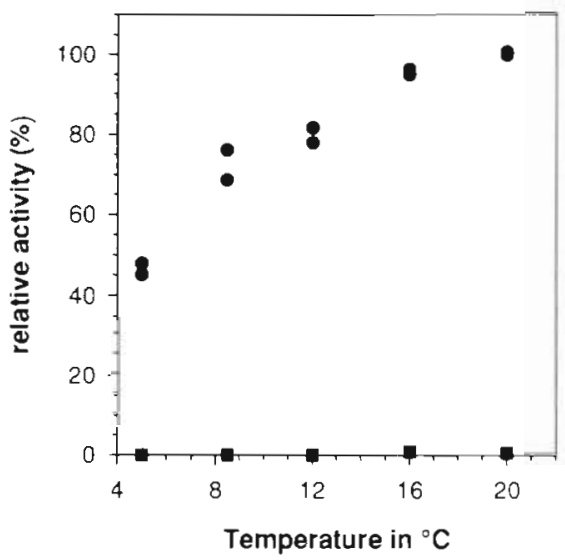

Fig. 2. Effect of temperature on DMSP-lyase activity in whole cells of axenic Phaeocystis sp., expressed as percentage of maximum activity, data are corrected for abiotic DMSP conversion; ( activity in whole cells, ( abiotic DMSP conversion

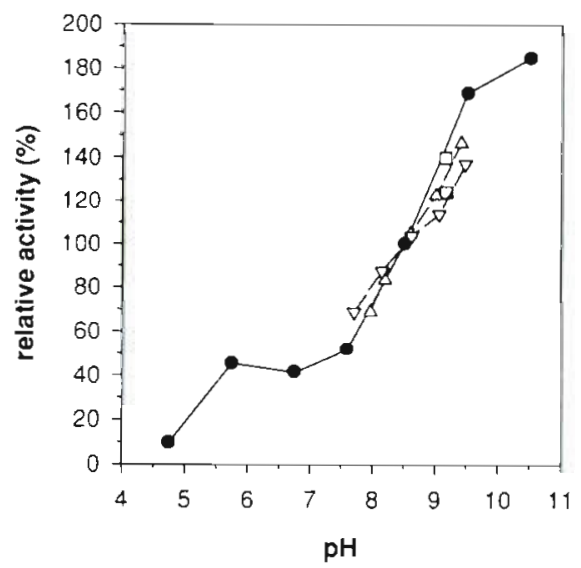

Fig. 3. Effect of pH on DMSP-lyase activity in crude extracts and whole cells of axenic Phaeocystis sp. cultures, expressed as percentage of the activity at $\mathrm{pH} 8.5$; data are corrected for abiotic DMSP conversion; (- - ) activity in extracts; activity in whole cells: $\left(--\Delta_{--)}\right.$(Tris-buffered), $(--\nabla--)$ (BTP-buffered). (a) (without buffer)

Effect of salinity and $\mathrm{NaCl}$ on enzyme activity: The DMSP-lyase activity profiles of extracts and whole cells in response to salinity were also comparable (Fig. 4). A gradual decrease of activity was observed with increasing ionic strength (expressed as salinity). Abiotic decomposition of DMSP increased gradually with salinity. At $50 \% \mathrm{~S}$ abiotic conversion had increased by a factor of 1.5 when compared with activities at $0 \% \mathrm{~S}$. Growth experiments at different salinities (Stefels unpubl.) had set limits on the salinity range used in the experiments with whole cells. The minor DMS release from intracellular DMSP during a $6 \mathrm{~h}$ period in a parallel series of shocked cultures indicated no severe damage to cells. In cultures which had experienced no or only slight salinity changes, $1.7 \%$ of total particulate DMSP 


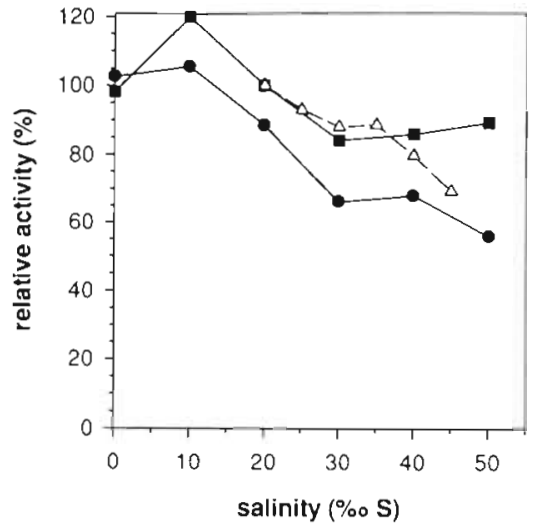

Fig. 4. Effect of salinity on DMSP-lyase activity in crude extracts and whole cell samples of axenic Phaeocystis sp. cultures, expressed as percentage of the activity at $20 \% \mathrm{~S}$ in seawater; data are corrected for abiotic DMSP conversion; activity in extracts: $(--)$ in seawater, $(-)$ in $\mathrm{NaCl}_{(--\Delta--)}$ activity in whole cells

(DMSP $)$ was released as DMS during this $6 \mathrm{~h}$ period; cultures with largest salinity changes (up as well as down) released $2.5 \%$ of DMSP as DMS. Total DMSP had increased slightly in all cultures during these $6 \mathrm{~h}$, indicating stable physiological conditions (Stefels et al. in press). Extracts were also incubated in $\mathrm{NaCl}$ solutions which inhibited DMSP-lyase activity more than seawater. In Fig. 4, activities are related to total ionic strength of the incubation medium. It should be noted that the $\mathrm{NaCl}$ content of seawater accounts for approximately $50 \%$ of the total salt. Except for deviations in the higher salinity regions, this might indicate that lyase inhibition is almost exclusively the result of $\mathrm{NaCl}$ inhibition. Maximum activity was found at $10 \% \mathrm{~S}$, equivalent to $160 \mathrm{mM} \mathrm{NaCl}$ in the $\mathrm{NaCl}$ series.

Kinetic properties: Because of the high abiotic conversion of DMSP in alkaline media, a suboptimal $\mathrm{pH}$ was chosen for kinetic experiments; at pH 8.3, DMSPlyase activity is approximately $50 \%$ of the $\mathrm{pH} 10.5$ activity. The Michaelis-Menten constant $\left(K_{\mathrm{m}}\right)$ and maximum velocity $\left(V_{\max }\right)$ in crude extracts were calculated from repeated experiments using LineweaverBurk plots. The apparent $V_{\max }$ varied between 0.35

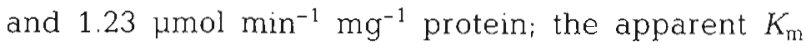
was determined as $2.25 \mathrm{mM}$ DMSP. Crude extracts retained almost $90 \%$ of their activity even after $24 \mathrm{~h}$ on ice. The interpretation of the $V_{\text {max }}$ values should be approached with caution, because only crude extracts were used and not pure enzyme.

Localization of DMSP-lyase: Cell fractionation experiments revealed that between 50 and $80 \%$ of total DMSP-lyase activity was associated with the membrane fraction, resulting in an increase of specific activity in this fraction by a factor of 3.5 compared with cell free extracts
The experiments with the thiol-reagent $p$ CMBS on whole cells demonstrated a clear reduction of DMSPlyase activity (Table 1). Inhibition was strongest at high $\mathrm{pH}$ values. Considering the nature of the chemical reaction - the formation of mercaptide ions that associate with the organo mercurial - this was to be expected. At a pCMBS concentration of $2 \mathrm{mM}$, less than $6 \%$ of the activity was left when the pH was 9.35 . It was assumed that at most $10 \%$ of $p$ CMBS in solution is dissociated into $\mathrm{HgCl}_{2}$, also a thiol-reagent. Although both inhibitors react with SH-groups, direct comparison of their reactivity can not be made. It is known that $\mathrm{Hg}^{2+}$ can react with either 1 or $2 \mathrm{SH}$ groups, whereas organic mercurials react with only 1. The difference in molecular structure may allow the inhibitors to react with different thiol groups within the enzyme. In general, however, $\mathrm{HgCl}_{2}$ is more reactive than pCMBS. In our experiments, samples with $200 \mu \mathrm{M} \mathrm{HgCl} \mathrm{Hg}_{2}$ exhibited a specific activity twice as high as samples with $2 \mathrm{mM} p \mathrm{CMBS}$, indicating that $p C M B S$ indeed did inhibit DMSP-lyase.

Discussion. The aim of this work was to carry out an initial characterization of the DMSP-lyase enzyme in Phaeocystis cells. By identifying the location of DMSPlyase and analyzing its activity under different experimental conditions, it was expected that this information would provide a better insight in the physiological role of DMSP-lyase.

Although unequivocal evidence for the localization of an enzyme can only be obtained in specific labeling

Table 1. Inhibitory effects of the thiol reagents $p$-chloromercuribenzenesulfonic acid ( $p \mathrm{CMBS}$ ) and mercury chloride $\left(\mathrm{HgCl}_{2}\right)$ on DMSP-lyase activity in whole cells of Phaeocystis sp. In each series, a non-inhibited sample was measured simultaneously as a reference

\begin{tabular}{|c|c|c|c|c|}
\hline $\begin{array}{l}\text { Assay } \\
\text { conditions }\end{array}$ & $\mathrm{pH}$ & $\begin{array}{c}p \mathrm{CMBS} \\
(\mathrm{mM})\end{array}$ & $\begin{array}{c}\mathrm{HgCl}_{2} \\
(\mu \mathrm{M})\end{array}$ & $\begin{array}{c}\text { Percentage } \\
\text { of maximum } \\
\text { activity }\end{array}$ \\
\hline Non-buffered & 9.06 & 0.5 & & 58 \\
\hline \multirow[t]{2}{*}{ 1. hincubation } & 9.02 & 1 & & 30 \\
\hline & 8.86 & 2 & & 17 \\
\hline Non-buffered & 9.06 & 0.5 & & 44 \\
\hline \multirow[t]{2}{*}{$2 \mathrm{~h}$ incubation } & 9.02 & 1 & & 20 \\
\hline & 8.86 & 2 & & 10 \\
\hline \multirow{6}{*}{$\begin{array}{l}20 \text { mM BTP buffer } \\
2 \text { h incubation }\end{array}$} & 8.61 & 0.5 & & 57 \\
\hline & 8.61 & 1 & & 47 \\
\hline & 8.59 & 2 & & 34 \\
\hline & 8.61 & & 50 & 63 \\
\hline & 8.62 & & 100 & 57 \\
\hline & 8.62 & & 200 & 53 \\
\hline \multirow{4}{*}{$\begin{array}{l}10 \mathrm{mM} \mathrm{BTP} \text { buffer } \\
2 \mathrm{~h} \text { incubation }\end{array}$} & 9.35 & 2 & & 6 \\
\hline & 9.43 & & 50 & 14 \\
\hline & 9.41 & & 100 & 13 \\
\hline & 9.42 & & 200 & 12 \\
\hline
\end{tabular}


experiments, our data provide strong evidence for an extracellular location of DMSP-lyase in Phaeocystis cells. Firstly, DMSP-lyase activities in extracts and whole cells clearly varied with buffer $\mathrm{pH}$ values. It has to be expected that under the conditions used the intracellular $\mathrm{pH}$ will be influenced only slightly by changes in extracellular $\mathrm{pH}$. The comparable responses of DMSP-lyase activity in whole cells and extracts thus provide a strong argument for an extracellular location of the lyase. Secondly, we found that DMSP-lyase in Phaeocystis is membrane-bound: 50 to $80 \%$ of total activity was present in the membrane fraction following cell fractionation. The $\mathrm{pH}$ response and this association with the membrane fraction suggest that the enzyme is bound to the outer surface of the cell membrane. An association with an intracellular membrane - e.g. vacuolar membranes that are involved in osmotic regulation - is not likely to be the case, considering the enzyme kinetics found in whole cells: instantaneous conversion of extracellular DMSP was observed in the low micromolar ranges, whereas intracellular DMSP concentrations, present at 1.50 to $200 \mathrm{mM}$ (Stefels \& van Boekel 1993), remained unaffected. Thirdly, the inhibition with pCMBS - a non-permeable thiol-reagent - strongly suggests an extracellular location.

The characteristics of the Phaeocystis DMSP-lyase (this study) allow some interesting comparisons with other known DMSP-lyases. Ishida (1968) and Cantoni \& Anderson (1956) studied crude enzyme preparations of the heterotrophic dinoflagellate Gyrodinium cohnii and the macroalga Polysiphonia lanosa, respectively, and also observed a requirement of DMSP-lyase for reduced thiol groups. In contrast, these authors observed an acidic $\mathrm{pH}$ optimum of the DMSP-lyase enzymes, whereas the $\mathrm{pH}$ optimum of this enzyme in crude extracts of Phaeocystis sp. was clearly alkaline. In $G$. cohnii, a pH optimum was found between 6 and 6.5 ; in P. lanosa, a pH optimum around 5.1 was observed that declined gradually on the alkaline side of this $\mathrm{pH}$. Recently, de Souza \& Yoch (1995) purified DMSP-lyase from a facultatively anaerobic marine bacterium. In their study, no requirement for reduced thiol groups was mentioned, the optimal $\mathrm{pH}$ was found to be 8 .

The reactivity of an enzyme with $\mathrm{pH}$ gives an indication of the identity of the amino acid residues involved in catalysis at the active site. Although the $p K a$ of this residue may vary considerably according to the nature of its environment within the enzyme, and therefore should be used with caution, the pKa of approximately 8.5 in Phaeocystis DMSP-lyase is, however, indicative of a cysteine residue. Also, the need for a reducing environment in extracts (DTT) and inhibition by pCMBS is consistent with an active role of cysteine residues at the active site of the enzyme. Under alka- line conditions, the deprotonated form of the thiol group of cysteine may act as proton acceptor when DMSP is cleaved into DMS and acrylate:

$$
\begin{gathered}
\left(\mathrm{CH}_{3}\right)_{2} \mathrm{~S}^{+}-\mathrm{CH}_{2}-\mathrm{CH}_{2}-\mathrm{COO}^{-} \rightarrow\left(\mathrm{CH}_{3}\right)_{2} \mathrm{~S}+ \\
\mathrm{CH}_{2}=\mathrm{CH}-\mathrm{COO}^{-}+\mathrm{H}^{+}
\end{gathered}
$$

What does this tell us about the physiological role of DMSP-lyase in Phaeocystis? The main function of DMSP in marine micro- and macroalgae may be the regulation of the osmotic potential of the cell. If we assume this to be the case in Phaeocystis, there are 2 ways of regulating intracellular DMSP concentrations upon changes of the water potential of the environment. One or both of the following mechanisms can be triggered: the production of DMSP can be affected, or a change in activity of the DMSP-lyase is induced. In up- and down-shock experiments with whole cells, however, we could not detect significant changes in intracellular DMSP content within $6 \mathrm{~h}$ after the shock (Stefels et al. in press). This is in contrast to other observations, e.g. of Hymenomonas carterae (Vairavamurthy et al. 1985). Also, the effect of salinity changes upon DMSP-lyase activity (Fig. 4) can not be regarded as an accurate mechanism in the regulation of intracellular DMSP concentrations, especially when considering the salinity range in which Phaeocystis can grow effectively: 25 to $40 \%$ S (Stefels unpubl.). Although intracellular DMSP concentrations do change when cultures are grown in different salinity media, these concentrations change only gradually rather than being regulated actively. We conclude from these observations that, in the case of Phaeocystis, DMSP can not be regarded as an osmoticum in the sense of an active regulator, although its high intracellular concentration of course contributes to the osmotic potential of the cell.

An active role for the extracellularly located DMSP. lyase in the cleavage of intracellularly produced DMSP would necessitate the need to transport DMSP across the cell membrane. In experiments with Phaeocystis cultures, a small but constant release of DMS could be observed during the exponential growth phase, amounting to $1-2 \%$ of intracellular DMSP per day (Stefels unpubl.). The presence of DMSP-lyase suggests that this release is beneficial to the alga and not merely the result of leakage. Further study into the physiological function of this catalytic process will be undertaken.

Acknowledgements. The authors thank Marc van de Maarel and Peter Quist for a steady supply of DMSP, Marion van Rijssel and Gert-Jan Euverink for useful discussions and practical hints, and Wim van Boekel for useful comments on the manuscript. Winfried Gieskes is acknowledged for his general support. This work was financially supported by the Commission of the European Community, Environment Programme, contract no. EV5V-CT93-0326. 


\section{LITERATURE CITED}

Blunden G, Smith BE, Irons MW, Yang M, Roch OG, Patel AV (1992) Betaines and tertiary sulphonium compounds from 62 species of marine algae. Biochen Syst Ecol 20:373-388

Cantoni GL, Anderson DG (1956) Enzymatic cleavage of dimethylpropiothetın by Polysiphonia lanosa. J biol Chem 222:171-177

Chambers ST, Kunin CM, Miller D, Hamada A (1987) Dimethylthetin can substitute for glycine betaine as an osmoprotectant molecule for Escherichıa coli. J Bacteriol 169:4845.4847

Dacey JWH, Blough N (1987) Hydroxide decomposition of dimethyl-sulfoniopropionate to form dimethylsulfide. Geophys Res Lett 14:1246-1249

de Souza MP, Yoch DC (1995) Purification and characterization of dimethylsulfoniopropionate lyase from an Alcaljgenes-like dimethyl sulfide-producing marine isolate. Appl environ Microbiol 61:21-26

Dickson DMJ, Kirst GO (1986) The role of $\beta$-dimethylsulphoniopropionate, glycine betaine and homarine in the osmoacclimation of Platymonas subcordiformis. Planta 167 : $536-543$

Dickson DMJ, Kirst GO (1987a) Osmotic adjustment in marine eukaryotic algae: the role of inorganic ions, quaternary ammonium, tertiary sulphonium and carbohydrate solutes. I. Diatoms and a rhodophyte. New Ptiytol 106:645-655

Dickson DMJ, Kirst GO (1987b) Osmotic adjustment in marine eukaryotic algae: the role of inorganic ions, quaternary ammonium, tertiary sulphonium and carbohydrate solutes. II. Prasinophytes and haptophytes. New Phytol 106:657-666

Edwards DM, Reed RH, Chudek JA, Foster R, Stewart WDP (1987) Organic solute accumulation in osmoticallystressed Enteromorpha intestinalis. Mar Biol 95:583-592

Gröne T, Kirst GO (1991) Aspects of dimethylsulfoniopropionate effects on enzymes isolated from the marine phytoplankter Tetraselmis subcordiformis (Stein). J Plant Physiol 138:85-91

Gröne T, Kirst GO (1992) The effect of nitrogen deficiency, methionine and inhibitors of methionine metabolism on the DMSP contents of Tetraselmis subcordiformis (Stein) Mar Biol 112:497-503

Ishida Y (1968) Physiological studies on the evolution of dnmethylsulfide. Mem Coll Agric Kyoto Univ 94:47-82

Kadota H, Ishida Y (1972) Production of volatile sulfur compounds by microorganisms. A Rev Microbiol 26:127-138

Keller MD, Bellows WK, Guillard RRL (1989) Dimethyl sulfide production in marine phytoplankton. In: Saltzman ES, Cooper WJ (eds) Biogenic sulfur in the environment. Symp Ser 393, American Chemical Society, Washington, DC, p 167-182

This note was submitted to the editor
Kirst GO, Thiel C, Wolff H, Nothnagel J, Wanzek M, Ulmke R (1991) Dimethylsulfoniopropionate (DMSP) in ice-algae and its possible biological role. Mar Chem 35:381-388

Ledyard KM, Dacey JWH (1994) Dimethylsulfide production from dimethyl-sulfoniopropionate by a marine bacterium. Mar Ecol Prog Ser 11095-103

Matrai PA, Keller MD (1994) Total organic sulfur and dimethylsulfoniopropionate in marine phytoplankton: intracellular variation. Mar Biol 119:61-68

Nishiguchi MK, Somero GN (1992) Temperature- and concentration-dependence of compatibility of the organic osmolyte $\beta$-dimethylsulfoniopropionate. Cryobılogy 29 : $118-124$

Paul JH (1982) Use of Hoechst dyes 33258 and 33342 for enumeration of attached and planktonic bacteria. Appl environ Microbiol 44:939-944

Stefels J, Dijkhuizen L, Gieskes WWC (1995) DMSP-lyase activity in a spring phytoplankton bloom of the Dutch coast, related to Phaeocystis sp. abundance. Mar Ecol Prog Ser 123:235-243

Stefels J, Gieskes WWC, Dijkhuizen L (in press) lntriguing functionality of the production and conversion of DMSP in Phaeocystis sp. In: Kiene RP, Visscher PT, Keller MD, Kirst GO (eds) Biological and environmental chemistry of DMSP and related sulfonium compounds. Plenum Publishing Corp, New York

Stefels J, van Boekel WHM (1993) Production of DMS from dissolved DMSP in axenic cultures of the marine phytoplankton species Phaeocystıs sp. Mar Ecol Prog Ser 97: $11-18$

Turner SM, Malin G, Liss PS, Harbour DS, Holligan PM (1988) The seasonal variation of dimethylsulfoniopropionate concentrations in near-shore waters. Limnol Oceanogr 33: $364-375$

Vairavamurthy A, Andreae MO, Iverson RL (1985) Biosynthesis of dimethyl sulfide and dimethylpropiothetin by Hymenomonas carterae in relation to sulfur source and salinity variations. Limnol Oceanogr 30:59-70

van Boekel WHM (1992) Interactions of Phaeocystis sp. with organic compounds and the microbial foodweb. PhD thesis, University of Groningen

van Diggelen J, Rozema J, Dickson DMJ, Broekman R (1986) ß-3-Dimethylsulphoniopropionate, proline and quaternary ammonium compounds in Spartina anglica in relation to sodium chloride, nitrogen and sulphur. New Phytol 103:573-586

Veldhus MJW, Admiraal W (1987) The influence of phosphate depletion on the growth and colony formation of Phaeocystis pouchetii (Hariol) Lagerheim. Mar Biol 95: $47-54$

White RH (1982) Analysis of dimethyl sulfonium compounds in marine algae. $J$ mar Res 40:529-536

Manuscript first received: April 27, 1995

Revised version accepted: August 3, 1995 